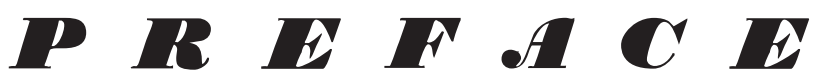

MAKING MOJO

How Two Hearts Can Beat As One

OVER a boisterous DeCADE, Tim O’Brien and I attended the same gritty rock 'n' roll shows, wrote high-energy music reviews and previews for papers like the Houston Press, and navigated academia, where we attempted to bridge our concerns for social justice with pop culture and an intensely felt sense of "living history." O’Brien pursued an exemplary focus on African American Studies and the blues, while I leaned toward examining punk rock culture's democratic impulses and multiculturalism. As a tough-minded, redheaded, fiery-tempered researcher of Irish descent, he could enumerate issues with rapid-fire aplomb, stitching together elements ranging from labor history and death penalty abolition to affordable urban housing, historic preservation, and fair trade movements. I would sit on his couch, simply trying to match the rigor of his thoughts, though I admit his sheer gusto often overwhelmed me.

For decades, when not pressing his ear to the feedback-drenched gyration of garage rock bands like the Dictators and Guitar Wolf, both bands whom he had befriended, he had immersed himself in the blues, especially at clubs like Antone's in Austin, Texas, and Fitzgerald's and The Continental in Houston, where he snapped eager photos of wise older players and young turks who filtered the past into their raucous sets with charm and panache, skill and fervor. He contributed articles about them to local papers and submitted entries on Sun $\mathrm{Ra}$, Chuck Berry, and Art Blakey to the Encyclopedia of African American History.

He eyed Lightnin' Hopkins endearingly, knowing this unparalleled bluesman had not been researched and scrutinized fully. This robust Texas legend soon became the subject of his dissertation, approved by Dr. William Ferris, 
professor of history at the University of North Carolina, and Dr. Douglas Henry Daniels, professor of African American history and jazz at the University of California, Santa Barbara. Upon completion, that work soon morphed into this book. O'Brien was compelled, seemingly deep in his DNA, to capture Hopkins's often raw-boned, sizzling, and incantatory oeuvre. O'Brien also understood that Hopkins's tunes effortlessly fused inveterate woe, fecund joy, and nuanced sociohistorical observations. And O'Brien collected at length.

Mining 135 secondary sources, he combed archives with eagerness and delved into Library of Congress collections, record company files in Berkeley, California, privately held collections, census and social security records, and probate court and police records. He unearthed elusive informants deep in Houston and logged endless hours tracking down musicians on the road who were willing to share their stories, eventually conducting I 30 oral interviews.

O’Brien was no arcane musicologist. He wanted to create and carve out a concisely woven, close-to-the-ground, insightful, and heavily detailed social and cultural history of Hopkins. Together, we edited his dissertation, wrote query letters to publishers, and began assembling this version. We intended the book not merely to appeal to a core audience of musical enthusiasts and others piqued by the text's links to Southern, African American, and American studies, but also to include cultural history readers. We believed the text would appeal to those interested in folklore, performance, and urban studies, and to social justice audiences as well.

Other recent work has also focused on the legacy of Hopkins, such as Lightnin' Hopkins: His Life and Blues by Alan Govenar. I believe O’Brien's primary research tends to be much more wide-ranging and inclusive, including the commentary of Grammy winner Dave Alvin and twice-Grammy-nominated Peter Case, well-admired Americana artists. Whereas Govenar might be considered more poetic and romantic, O'Brien aimed for historic depth and breadth. He desired to expose the modern ripples of the subject, tracing how current artists explore the "usable past" of the blues to address their own artistic concerns and themes.

The book debunks several myths. For instance, Hopkins did not refuse song royalties and record only for cash payments. It also illustrates and explains his idiosyncratic business practices, such as shunning professional bookers, managers, and publicists. We discuss recording sessions at length and also elucidate his lyrics, which embody a keen sense of poetry that transforms mundane aspects of life, from beans to telephones, into vibrant tropes. His diverse song content far exceeds rudimentary blues themes; he readily grasped issues of the day, such as space exploration, the Vietnam War, and lesbianism. In addition to surveying 
rock 'n' roll guitar players such as Jimi Hendrix and Stevie Ray Vaughan, the narrative recounts Hopkins's influence on Miles Davis, John Coltrane, Tom Waits, and Bob Dylan, who based his tune "Leopard Skin Pillbox Hat" on a Hopkins song.

Hopkins's music style mutated and adapted to the era of rhythm and blues. After recording alone on acoustic guitar for years, he grabbed an electric guitar and gyrated to the new beats, delivering a modern blues idiom. By the late I950s, though, rock 'n' roll overshadowed country blues, burying Hopkins's career. Starting in the I960s, he enjoyed a storied second career as a folk blues artist who gained worldwide acclaim and booked international tours. Indeed, Hopkins helped pioneer the folk and blues revivals of the I96os, even grafted his music onto the rock scene while performing with and influencing notable bands such as the Grateful Dead and Jefferson Airplane. This inventive decade is discussed by performers such as Ramblin' Jack Elliott, Barbara Dane, and Mose Allison. Last, Hopkins's appearances at important nightclubs like the Ash Grove in Los Angeles, the Village Gate in New York City, and the Armadillo World Headquarters in Austin, Texas, paint a picture of an American music world yet again on the cusp of change.

While investigating the pained history of sharecropping in Texas, and becoming familiar with the heavy-handed Houston police force that maintained order in Houston during the height of the civil rights movement, O'Brien chronicled Lenwood Johnson, an activist who had fought courageously for a local housing development called Allen Parkway during the I99os. O’Brien and Johnson fought to preserve and revitalize Freedmen's Town, a historic free black neighborhood near a Jewish cemetery that O’Brien called home and Hopkins once frequented.

O'BRIEN BECAME ILL WITH CANCER IN 2009, and the outlook was immediately worrisome. Tenaciously, by monitoring his health closely and adopting a strict diet, he was able to fend off the worst symptoms for nearly two years. In the spring of $20 \mathrm{II}$, the cancer had spread, the treatments were limited, and the manuscript languished, mostly complete. I openly encouraged O’Brien to tackle the final chapters and finish the manuscript that could become his signature piece of writing. With relatives nearby, I came to his side, helping him type the last portions. Deep pockets of his memory remained intact: he could recall Hopkins's contracts and concert details with ease, yet he experienced difficulty sending an e-mail or cutting and pasting a portion of text. The cancer's journey through his brain was mysterious. Yet he never complained. His rectitude was unwavering. He thought of his wife, his child, and Lightnin' Hopkins. 
When he died, friends and family gathered at his home to hear radio broadcasts of news events in which O'Brien had participated, including his efforts to end the death penalty in Texas, to push the University of Houston to affiliate with the Worker Rights Consortium, to found UH Students Against Sweatshops and UH Students for Fair Trade on campus, and to publicize and lobby on behalf of the Free Man's Neighborhood Association. This side of O'Brien somewhat surprised his immediate family, who were more familiar with his role as father, student, and music writer. I knew of those struggles, too, but I was more gripped by his writing and love of music.

Ironically, the man whose sentences I helped finish had organized two major fund-raisers during recent years. On behalf of Alejandro Escovedo, suffering from acute hepatitis, and Peter Case, who was nearly struck down from a severe heart attack, O'Brien had gathered a coterie of talents-Joe Ely, Gurf Morlix, and James McMurtry - to provide thousands of dollars in medical relief. As O'Brien slipped away, we closed the envelopes full of Hopkins news clippings and Xeroxes, filing away his research, and I recalled such volunteerism.

He was more than just a chronicler of history, an honest and invigorating music fan and friend, and a complex community leader. He was a comrade who understood that more than music was at stake. Telling the story of Hopkins is telling the story of America, writ large into the fabric of one person's hardscrabble life. It is the story of art that perseveres despite flawed economic systems, of songs that penetrate past the built-in obsolescence of music fads and fashions, and of stories that evince the historic wounds of America, even when told spontaneously, off-the-cuff, slightly tipsily, and maybe, in any given version, for one night only.

DAVID ENSMINGER

December 2011 


\section{DID D D}


THIS PAGE INTENTIONALLY LEFT BLANK 